\title{
The Policy of Community-based Disaster Management in Disaster-resistant Village at Semarang City
}

\author{
Martien Herna Susanti ${ }^{1}$, Setiajid ${ }^{2}$ \\ \{martien@mail.unnes.ac.id ${ }^{1}$, setiajid@mail.unnes.ac.id² \\ Universitas Negeri Semarang, Indonesia ${ }^{1,2}$
}

\begin{abstract}
The purpose of the study is to elaborate the community-based disaster management policies and its obstacle on the implementation in the disaster-resistant village at Semarang City. The research is descriptive explorative. The research was held in Semarang city, the subject is disaster-resistant village (later will be abbreviated into KTB) community. Data gathered by interviews, observation, documentation, and focus group discussions. The key informants are the facilitators of KTB, chief of the village, village official, volunteers, and KTB community. The results showed that KTB that established in 2018, is the development of Village Disaster Preparedness program that established in 2017 as the implementation of the Local Government Regulation of Semarang City Number 13 in 2010, about the Implementation of Disaster Management in Semarang city. The concept of KTB based on disaster management community or CBDP (Community Based Disaster Preparedness) that are now become KTB in Semarang city. Conclusion of the study is the policy management of community-based disaster management have not been able to encourage grassroots communities to manage disaster risk in disaster-prone areas. The obstacle on the implementation lay on the community itself and the paradigm about disasters based on its social values, religious beliefs, and of the tradition people embraced.
\end{abstract}

Keywords: Disaster Management, Community Policy, Disaster-Resistance Village.

\section{Introduction}

Semarang City is one of the districts/cities in Central Java Province that highly risk toward disasters. Those are three characteristics of Semarang region, those are beaches, plains, and hills, that makes Semarang has a high potential disaster. The Semarang City Disaster Management Agency (BPBD) noted that disasters that generally occur in Semarang City are floods, landslides, tornadoes, collapsed houses, fallen trees, fires, and droughts. The article discusses community-based disaster management policies in disaster-resistant villages (KTB) in Semarang City as an effort to reduce disaster threats and community vulnerability, as the community improvements of preparedness capacity in planning and implementing the disaster management. Community-based disaster management is an approach that encourages grassroots communities to manage disaster risk at the local level. It requires a series of efforts which includes the ability to have self-awareness of the threats and facing disaster risks, reduce and monitor and then evaluate their performance.

In several developed countries, the government's efforts to reform disaster management policies focusing on the ability of communities to take actions in hazard mitigation, emergency preparedness, and emergency response. For example, the Integrated Community- 
Based Disaster Management Program (ICBDM) in Taiwan that has succeeded in strengthening community capacity in disaster management. Through a participatory process, community members have succeeded in learning how to analyze vulnerable conditions, find problems, develop solutions and form organizations to carry out disaster management tasks $[1]$.

Nowadays the management of disaster risk using top-down shortcomings is no longer effective to reduce the threat of disasters that occur in disaster-prone areas, the technology and experts are still very much needed. Efforts to reduce disaster risk are more effectively carried out through suppressing local capacity development [2] as a means of increasing resilience to natural hazard events, prevent disasters and adapt to the environment. Disaster according to Semarang City Regulation Number 13 of 2010 [3] concerning the Implementation of Disaster Management in Semarang City Article 1 paragraph (9) states that disaster is an event or series of events that threaten and disrupt the lives and livelihoods of people caused by natural factors and/or non-natural or human factors resulting in human lives, environmental damage, property losses, and psychological impacts.

The policies related to disaster management owned by the City of Semarang are contained in the Regional Regulation (Perda) of Semarang City Number 13 of 2010 concerning the Implementation of Disaster Management in Semarang City, which is the implementation of Law Number 24 Year 2007 concerning Disaster Management article 4 which states, that disaster management aims to protect the public from the threat of disaster. Furthermore, the BNPB Regulation Number 3 of 2008 concerning the Guidelines for Establishing a Regional Disaster Management Agency, stipulates that the regional government is responsible for protecting the public from the threat and impact of the disaster. The formation of the urban disaster response itself refers to the BNPB Regulation Number 1 of 2012 about General Guidelines/District Village Disaster Resilient [4]. Village of Tangguh Disaster is rural/urban neighborhoods have an independent ability to adapt and face the potential hazards, as well as recover quickly from the effects of disasters that harm. In the Tangguh Bencana Village, the community is actively involved in reviewing, analyzing, handling, monitoring, evaluating and reducing disaster risks in their area, especially by utilizing local resources to ensure sustainability. The aim of disaster-resistant village are: (1) to protect people living in areas that are prone to disasters, (2) to enhance the role of society, especially vulnerable groups, to manage the resources in order to reduce the disaster risk, (3) increasing community institutional capacity in managing resources and maintaining local wisdom for disaster risk reduction, (4) increasing government capacity in providing resource and technical support for disaster risk reduction, (5) increasing the collaboration between stakeholders, local government, the private sector, universities, NGOs, community organizations and other groups that care.

Franck Lavigne et al [5] in his article, "People's behavior in the Face of Volcanic Hazards: Perspectives from Indonesian Communities", emphasized the role of cultural factors in making people's behavior in facing natural hazards emphasized by anthropologists. Cultural theorists emphasize that individual decisions to deal with the dangers of various origins are embedded in social and cultural values [5]. Anthropological and sociological perspectives state that people's behavior is the only threat posed by the dangers faced by these individuals. The danger is rather filtered by individual perceptions of the world, which vary according to social values, religious beliefs, community traditions, and attachment to the place. Risks can be predicted by asset value under certain communities. The risk may differ from the perceived risks. Some significant studies have highlighted the role of cultural factors in volcanic hazards mostly in Southeast Asia and the Pacific [5]. The burden of social and economic barriers has 
been emphasized by proponents of a radical interpretation of disasters, which emerged in the 1970s. The paradigm state that people's behavior in facing natural disaster often does not depends on natural damages but it is limited by social, economic and political forces beyond the control of the individuals themselves. Disasters are seen as daily obstacles in which the victims are marginalized in three ways: geographically because they are forced to live in areas prone to disasters, socially because they are poor and cannot protect themselves from natural and political dangers because of their voices easily ignored. The perspective emphasizes people's vulnerability or their vulnerability to suffering damage if natural disasters happen. The vulnerability emphasizes the condition of society, to see danger as a disaster. Human vulnerability in facing natural hazards, among others, include the welfare and human strength, resilience of their livelihoods, their ability and willingness to protect themselves, the protection of society and social capital [5].

Bajek et al [6] in their research entitled: "Japan's Jishu-Bosai-Soshiki Community Activities: Analysis of Its Role in Participatory Community Disaster Risk Management", describes Jishu-bosai-soshiki, or Jishubo namely autonomous organizations or environmental associations for disaster relief, preparedness, and disaster relief. Local associations such as Jishubo played an important role in participatory disaster management in Japan. Thanks to this social institution, it is possible to mobilize citizens to participate in disaster management programs. We found weaknesses, that most participants in Jishubo were parents who joined with reasons that were not fully related to disaster preparation or mitigation. Conclusions in the study, that the new social approach needed to increase participation is not merely an initiative from the government.

The research of Habibullah [7], generating a comparison community-based disaster management policy between the disaster-resilient village and Disaster-resistant village. The concept of disaster-resilient village tends to be a brand, while in a disaster-resistant village, disaster is a concept of the area of the village itself. The objectives of the disaster preparedness village tend to be more complex, namely providing community understanding and awareness, forming networks and strengthening social interactions, organizing, ensuring sustainability, optimizing the potential and resources, but disaster-resilient villages are more likely to be efforts to increase community-based response. The approach also tends to maximize the use of local resources, including labor, material and organization. Successful disaster management practices must involve collaboration between the community and the relevant agencies. Local communities should be aware of would be the risk of caring for action to deal with the risk. Communities may need technical assistance, material assistance and assistance in building their capabilities [8].

Buckland and Rahman [9] study, entitled "Community-based Disaster Management during the 1997 Red River Flood in Canada", highlighted the relationship between public preparedness and response to natural disasters and community development patterns towards the Red River Flood in 1997 by three communities at countryside namely Roseau River, Rosenort, and St. Jean Baptiste in Manitoba, Canada. The results of his research show the importance of social capital for participatory and sustainable development. Like development management, effective disaster management requires participatory social organizations that promote collaboration and problem solving. Community response is very dependent on individual perceptions of disasters. Perception is the experience of objects, events or relationships that are obtained by deducing information and interpreting messages. The perception of each individual can be very different even though what is observed is the same [10]. Factors that influence people's perceptions in supporting CBDP can be linked to external 
factors that influence perception (novelty, repetition) and internal (interests, biological conditions, and habits) [10].

\section{Research Methods}

The research using descriptive exploratory, it is the type of research that aims to describe a social phenomenon in depth without trying to analyze the relationship and the effect of one variable to another variable [11]. The research located at Semarang with the research subject is disaster resistant Village community in Semarang City. The research subjects will be purposively netted namely $\mathrm{T}$ Village Facilitators who consider Disasters, Village Head, Village Framework, volunteers, and the community. Data is captured through interviews, observation, documentation, and focus group discussions. Data analysis to test the feasibility of the model and the effectiveness of the device was carried out by descriptive and quasiexperimental analysis. Informants in this study conducted with key informants (key informant), the facilitator Village Disaster Response, Head, Village devices, and public communities in the Village-resistant Disaster.

\section{Results and Discussion}

The sustainability program of Disaster-resistant village, the National Disaster Management Agency (BNPB) through the Regional Disaster Management Agency (BPBD) Semarang Regulation at 2017 form 11 Village-resistant Disaster in Semarang, those are Wonosari, Gondoriyo, Kalipancur, Randusari, Mangkang Wetan, Mangunharo, Sukorejo, Kemijen, Rowosari, and Kaligawe. Furthermore at 2018 there are five Disaster-resistant Villages includes Beringin, Wates, Tinjomoyo, Trimulyo, Tanjung Mas, and in 2109 it was reestablished five villages those are Meteseh, Karangroto, Muktiharjo Kidul, Lempongsari, Krobokan. If in 2017 the resilient urban village funding source from the National Budget State (APBN), then since 2018 and at 2019 the village management will come from the Regional Budget (APBD). This is a consequence of the Regents/Mayors at the district/city level to carry out the functions of coordination, cooperation, strengthening institutional capacity, increasing funding sources, funding and facilitating activities at the district/city level. Related to the management of information systems disaster, since 2017 Semarang government has Early Warning System (EWS), which installed in four villages, those are Sukorejo, Gunungpati for type of EWS landslides and in 2018 there are three for the types of flood EWS installed in the Beringin Village, Meteseh Village Tembalang District, Karangroto Village, Genuk SubDistrict [12].

The initiator of disaster risk reduction in urban prone disaster resilient done through local resources mobilization such as the deployment of all assets, both material and social capital. Including the local wisdom of the community as the main capital. The ability to mobilize resources is one measurement to see the village resilience. The mobilization of resources principle of sustainable management at the same time also increasing the capacity of the environment against various disaster risks by referring to the rights and risk of the community. The problems faced are generally related to efforts to preserve environmental functions in disaster-resistant villages, due to changes in the land function that was originally green land that are now turned into residential land so that it is very vulnerable to landslides as in 
Kalipancur, Randusari, Sukorejo, Tinomoyo, meteseh, and Lempongsari Villages. Urban villages that are flood-vulnerable, those are Wonosari, Gondoriyo, Kalipancur, Mangkang Kulon, Mangkang Wetan, Mangunharjo, Kemijen, Beringin, Wates, Trimulto, Tanjungmas, Meteseh, Karangroto, Multiharjo Kidul, and Krobokan. The activities carried out in disasterresistant villages were in the form of training volunteers to adapt to potential disasters, providing the ability to recover locations affected in each resilient urban village in collaboration with Basarnas, SAR, Brimob, and Polri. Before conducting simulations in the field, planning activities were carried out, including drafting work groups, forming volunteer forums, making risk and evacuation maps, and preparing disaster management. The characteristics of CBDP (Community Based Disaster Preparatory) are adjusted to the vulnerability of disasters in each region, so that are different in each village. To ensure the sustainability of the program, community has been involved in the process of assessment, planning and implementation.

The Disaster Risk Reduction (FPRB) forum was originated from various organization and related fields, the formation of volunteers, and the establishment of a communication FPRB forum members.

In the early stages BPBDs Semarang provide encouragement and facilitate the village to plan and implement the KTB programs. One thing that is urgent for KTB is the capacity to mobilize the resources that exist through the principle of sustainable management of resources while improving the capacity of the environment against various risks disaster by referring to the people's needs and rights includes local knowledge society as the main capital. The activity of village/sub-resilient disaster in the form: (1) Risk/District Village includes assessing threats, assess vulnerabilities, assess kapasit as, analyzing the disaster risk, (2) planning of the disaster resilience and Contingency Planning/District Village that covers, Disaster Management Plan Rural/Village, (3) The forming PRB forum, (4) Enhancing the capacity of residents and officials in the NT, (5) the blending of DRR into the Plan of Rural Development and Legalization, (6) enforcing the PRB in Village, and (7) Checking, Evaluation and Reporting Program at the Village.

Obstacles in implementing CBDP policies are: (1) increasing community institutional capacity. There is a kind of KTB institutionalization of the Forum for Disaster Risk Reduction (FPRB) and the team. Based on BNPB Regulation No. 3 of 2008 on Guidelines for the Establishment of Regional Disaster Management Agency, then KTB Semarang level is KTB Pratama, because: (1) KTB formed in early stage risk assessment, risk management, and vulnerability reduction, (2) as an initial effort to increase the capacity of disaster preparedness and response. Due to the new institution, a continuous effort are needed to increase the KTB level to intermediate level and then to the highest level. In general, the Semarang citizen have realized the disaster potential on the area where they live, even the formation of CBDP according to informants, provides a lot of knowledge for the community to overcome the disaster vulnerability. Society perception at KTB are influenced by several factors, those are social values, religious beliefs, community traditions, and attachment to their living place.

\section{Conclusion}

Based on the BNPB Regulation Number 3 of 2008 concerning Guidelines for Establishing a Regional Disaster Management Agency, the KTB of Semarang City is KTB Pratama. The CBDP (Community Based Disaster Preparedness) process carried out includes: selecting 
communities, building trust, disaster risk assessment, management planning, building organizations, implementation, monitoring, and evaluation. Constraints to mobilizing resources as one measurement to see the village resilience that are constrained by increasing community institutional capacity, and community perception in interpreting disasters according to social values, religious beliefs, community traditions, and attachment to their living place.

\section{References}

[1] Y. Zhou et al., "The effect of land use planning (2006-2020) on construction land growth in China," Cities, vol. 68, pp. 37-47, 2017.

[2] K. M. Allen, "Community-based disaster preparedness and climate adaptation: local capacitybuilding in the Philippines," Disasters, vol. 30, no. 1, pp. 81-101, 2006.

[3] Pemerintah Kota Semarang, "Peraturan Daerah Kota Semarang Nomor 13 Tahun 2010 tentang Penyelenggaraan Penanggulangan Bencana di Kota Semarang," 2010.

[4] BNPB, "Peraturan Kepala Badan Nasional Penanggulangan Bencana Nomor 1 Tahun 2012 tentang Pedoman Umum Desa/Kelurahan Tangguh Bencana,” 2012.

[5] F. Lavigne et al., "People's behaviour in the face of volcanic hazards: Perspectives from Javanese communities, Indonesia," J. Volcanol. Geotherm. Res., vol. 172, no. 3-4, pp. 273-287, 2008.

[6] R. Bajek, Y. Matsuda, and N. Okada, "Japan's Jishu-bosai-soshiki community activities: analysis of its role in participatory community disaster risk management," Nat. Hazards, vol. 44, no. 2, pp. 281-292, 2008.

[7] H. Habibullah, "Kebijakan Penanggulangan Bencana Berbasis Komunitas: Kampung Siaga Bencana dan Desa/kelurahan Tangguh Bencana,” Sosio Inf., vol. 18, no. 2, 2013.

[8] R. Handayani, "Analisis Partisipasi Masyarakat dan Peran Pemerintah Daerah dalam Pelaksanaan Manajemen Bencana di Kabupaten Serang Provinsi Banten,” in Simposium Nasional Otonomi Daerah 2011, 2011.

[9] J. Buckland and M. Rahman, "Community-based disaster management during the 1997 Red River Flood in Canada," Disasters, vol. 23, no. 2, pp. 174-191, 1999.

[10] J. Rakhmat and P. Komunikasi, "Remaja Rosdakarya." Bandung, 2005.

[11] R. Bogdan and S. J. Taylor, "Pengantar Metode Penelitian Kualitatif," Terjem. Ali Furchon. Surabaya Usaha Nas., 1992.

[12] B. K. Semarang, "Badan Penanggulangan Bencana Daerah Pemerintah Kota Semarang. (2019). Daftar KTB/Katana (Kelurahan Tangguh Bencana) di Kota Semarang.," 2019. 